\title{
Portuguese-SPEAKing Countries AND The Challenge OF A TECHNOLOGICAL CIRCUMNAVIGATION
}

\author{
Moisés de Lemos Martins
}

\begin{abstract}
In this article, I propose the assumption that we are making a technological journey, analogous in many respects to European ocean voyages of the $15^{\text {th }}$ and $16^{\text {th }}$ centuries (Martins, 2015a, $2017,2018 \mathrm{a}, 2018 \mathrm{~b}$ ). Thus, I confront the technological nature of the current financial globalization and the commercial nature of European maritime expansion. Whereas the first journey resulted in the colonization of peoples and nations, in the second journey we moved, in a century and a half, to that which Edgar Morin called the "colonization of the spirit" of the entire human community (Morin, 1962). Within this context, I took into consideration the consequences, for culture, of the acceleration of the time via technology, which has mobilized human beings, "totally" (Jünger, 1930) and "infinitely" (Sloterdijk, 2010), in view of the urgencies of the present (Martins, 2010). On the other hand, I will use post-colonial studies to situate transnational and transcultural identities, by examining Portuguese-speaking communities within the context of the "battle of languages," to use an expression coined by Mozambican linguist Armando Jorge Lopes (2004). This is why I will consider "technological circumnavigation" (Martins, 2015a, 2017, 2018a, 2018b), to be undertaken by every Portuguese-speaking country, like a fight for the world's symbolic ordering (Bourdieu, 1977, 1979, 1982), where we raise hegemony language-related problems and those pertaining to political, scientific, cultural and artistic subordination (Martins, 2015b). This is, therefore an electronic journey, using sites, portals, social media, digital repositories and archives, as well as virtual museums. What's more, the viewpoint adopted is that which states a great language of cultures and thinking, such as Portuguese, likewise cannot avoid being a great language of human and scientific knowledge.
\end{abstract}

KEYWORDS

Post-colonialism; Lusophony; Portuguese language; transcultural and transnational identities; technological circumnavigation

\section{OS PAÍSES LUSÓFONOS E O DESAFIO DE UMA CIRCUM-NAVEGAÇÃO TECNOLÓGICA}

\begin{abstract}
RESUMO
Proponho neste artigo a hipótese de estarmos a fazer uma travessia tecnológica, em muitos aspetos análoga à travessia marítima europeia dos séculos XV e XVI (Martins, 2015a, $2017,2018 a, 2018 b$ ). Coloco, pois, em confronto a natureza tecnológica da atual globalização financeira e a natureza comercial da expansão marítima europeia. E se da primeira travessia resultou a colonização de povos e nações, com a segunda travessia passámos, em século e meio, àquilo a que Edgar Morin chamou a "colonização do espírito" de toda a comunidade humana (Morin, 1962). Neste contexto, tomei em consideração as consequências, para a cultura, da aceleração da época pela tecnociência, que tem mobilizado o humano, "total" (Jünger, 1930) e "infinitamente" (Sloterdijk, 2010), para as urgências do presente (Martins, 2010). Por outro lado, vou situar nos estudos pós-coloniais as identidades transnacionais e transculturais, analisando as comunidades lusófonas no contexto da "batalha das línguas", para utilizar uma expressão do
\end{abstract}


linguista moçambicano, Armando Jorge Lopes (2004). Por essa razão, vou considerar a "circum-navegação tecnológica" (Martins, 2015a, 2017, 2018a, 2018b), a empreender por todos os países do espaço lusófono, como um combate pela ordenação simbólica do mundo (Bourdieu, 1977, 1979, 1982), onde se colocam os problemas de língua hegemónica e de subordinação política, científica, cultural e artística (Martins, 2015b). Trata-se, pois, de uma travessia eletrónica, utilizando sites, portais, redes sociais, repositórios e arquivos digitais, e ainda, museus virtuais. $\mathrm{E}$ o ponto de vista adotado é o de que uma grande língua de culturas e de pensamento, como é a língua portuguesa, não pode deixar de ser, igualmente, uma grande língua de conhecimento, humano e científico.

\section{Palavras-Chave}

Pós-colonialismo; lusofonia; língua portuguesa; identidades transculturais e transnacionais; circum-navegação tecnológica

\section{LANGUAGE POLICY AND LUSOPHONY ${ }^{1}$}

Right at the opening of the study, "Can the subaltern speak," Gayatri Spivak confronts the authors, whom we in the West identify as the "difference thinkers" (especially, Marx, Althusser, Derrida, Foucault, Deleuze, Guatarri and Lyotard), with a vital question. In these authors, we also see Western reason being expressed, and not the reason of that which we identify as "the other". The other's power (Marx and Foucault), the other's wish (Deleuze and Guatarri) and the other's interest (Marx and Althusser) do not have, in the "philosophy of difference" (Derrida and Lyotard) the "other's" voice. That is why "the other" is not the "subject"; it's merely the alienation of a subject, as this is nothing more than a projection of the Western subject, with its categories and context. As a result, Gayatri Spivak proceeds to make a closed criticism of "discussing the subject", as done by these iconic thinkers. And, in so doing, this calls into question the depiction of the Third World subject, as projected by Western discourse. As we know, the center never stopped projecting and conceptualizing what it regards as its peripheries: Africa, the Orient, Latina America - in short, the Third World. Gayatri Spivak (1988/1994, p. 66) thus concludes that radical criticism, which we observe in these Western authors, is not all that radical, as it manifests "an interested wish to preserve the Western subject, or the West as Subject".

While taking Lusophony as an object, I use this article to question the political, strategic and cultural condition of Portuguese-speaking countries, within the context of globalization, which is, above all, a financial and technological reality, with a hegemonic language (English), and which, because of this, sees all of these countries faced with the problem of their linguistic, cultural, political and scientific subordination. That is to say, the common condition of the political subordination of Portuguese-speaking countries is expressed by the common condition of subordination of their language, cultures and knowledge. However, though we can imagine, for Portuguese-speaking countries, a dream of converging cultures, arts and knowledge, the Portuguese-speaking area, in its

\footnotetext{
'Research developed in the context of the project "Memories, cultures and identities: how the past weights on the presentday intercultural relations in Mozambique and Portugal?", supported by Aga Khan Development Network and Portuguese Foundation for Science and Technology.
} 
territorial, cultural and artistic multiplicity and diversity, still remains a multi-centered, hierarchical, asymmetric and largely unknown area for citizens of the very countries comprising it.

Conditions at the time are technological. And that is why I am led to regard cyberspace as a new place for scientific knowledge, undoubtedly in English, with communication policies jumping onto websites, electronic portals, social media, digital repositories and virtual museums. However, from my viewpoint, the new place for scientific knowledge lies in the Portuguese language.

The notion of Lusophony is, thus, found within the context of the current debate on the globalization of knowledge and digital culture. Plus, for all peoples, globalization today is presented as an inexorable destination, of mobilization toward a global market (Martins, 1998): to a certain extent, we see the unique and definitive identity of individuals from every nation, henceforth mobile and flexible (with no social rights), mobilizable (responding to market needs), competitive (adopting production logic) and performing (achievers of success) (Martins, 2015b, pp. 9-10).

Under these circumstances, the transcultural and transnational space of Portuguese-speaking peoples cannot help but be confronted with a strategic challenge: finding itself, today, on the same side of the fence, of countries that are dominated, subordinate, and constantly pushed toward the periphery of hegemonic globalization, a space spoken in a single language (English), Lusophony can be regarded as a technological and intercultural circumnavigation, a journey, to be undertaken by all Portuguese-speaking peoples, in order to achieve inter-knowledge, cultural, scientific, social, political and economic cooperation, as well as the assertion of diversity in the world, in short, a circumnavigation that opens up to the furthest reaches of human development.

Circumnavigation classically highlights the experience of ocean voyages and of overcoming the set limits of seas, lands and knowledge. Circumnavigation, therefore, constitutes a good metaphor to characterize the Portuguese-speaking (ad)venture, not only of the culture of diversity and intercultural communication, but also of the science achieved in Portuguese. The technological circumnavigation shall, thus, be undertaken via websites, portals, social media, digital repositories and archives, as well as virtual museums.

The notion of Lusophony undoubtedly is not consensual in Portugal, or in the extended area of Portuguese-speaking countries. First and foremost, we need to bear in mind the multicultural and heterogeneous identity, which constitutes each community in the Portuguese-speaking area, as well as the non-Western worlds' intricate and ambivalent relation with former colonizing countries ${ }^{2}$. And likewise, we need to consider the media of each of the countries in the Portuguese-speaking area, within the context of their identity-related strategies, be they local, national or transnational.

To summarize the arguments that have been raised against the notion of Lusophony, I summon Miguel Tamen, Literature Professor at Lisbon University. In several press articles and interviews ${ }^{3}$, Miguel Tamen denounces Lusophony, as he did not understand

\footnotetext{
${ }^{2}$ Regarding the multicultural and heterogeneous identity of the Portuguese-speaking area, see, for example, the study I have conducted with Regina Brito concerning Mozambique and Timor-Leste (Brito \& Martins, 2004).

3 See, for example, the interviews given, on the one hand, to $i$ newspaper (April 24th, 2012) and, on the other hand, to Ler
} 
that people and countries can be united by a single language. In his view, it is a pipe dream to imagine language as an asset. And, while not being an asset, there would be no reason to defend it. However, and above all, Lusophony is, to Miguel Tamen (2012), an incorrect notion, as, in Portugal, this corresponds to "a sort of left-wing colonialism". Following the disappearance of the Portuguese colonial empire, Lusophony would be nothing more than its spiritual replacement. Today, it would replace the former words of "faith, empire and religion" (Tamen, 2012). In short, Lusophony would stem from the mirage of a Portuguese exceptionalism - this exceptionalism, which imagined Portuguese colonization as a unique case in the history of European colonization, now imagines the Portuguese as a different people from all the others (Tamen, 2012) ${ }^{4}$.

This viewpoint is also shared in Brazil, by several authors, including Carlos Alberto Faraco $(2012,2016)$. To summarize, Faraco believes that the project of Lusophony is a "pipe dream", particularly because its discourse consists of extolling abstract values, such as the "fellowship of peoples" and the "harmony of cultures" (Faraco, 2012).

In the meantime, in the article he published in the Observador newspaper, Miguel Tamen (2016) defends an upsetting viewpoint on language policy. He believes in the disappearance of every Portuguese chair, paid by the Portuguese government at foreign universities; every professor of Portuguese, paid by the Portuguese government, outside Portugal; every rule of spelling, and every attempt, in his view grotesque, to suggest that, by writing the same way, people will speak the same way. To conclude his viewpoint, Miguel Tamen proclaims the following: let's do away with the Camões Institute, because "the best and only decent language policy is: none" (Tamen, 2016).

The matters regarding the Portuguese language and Lusophony are important, in my view, due to the fact that the invoking of a language and a common transcultural and transnational space constitute, especially from a strategic standpoint, relevant issues, both for Portugal and for every Portuguese-speaking country, as well as for their diasporas.

At all times, human communities were confronted with two vital issues, with the problem of the order, in the attempt to respond to the requirement for community living; and also, with the problem of history, by inquiring on the possibilities of human action. In these aspects, our time is no different from any others. And the debate on the Portuguese language and, thereby, on constituting a Portuguese-speaking community, I consider these to be ways of responding, both to the requirement of community living and to the possibilities of human action.

It is true that construction, in diversity, of the large community of cultures, which the Portuguese-speaking space comprises, calls for a reflective look and how the interaction

\footnotetext{
magazine (no. 149, Spring 2018, pp. 20-33). See also the opinion article published in the Observador newspaper (January $\left.8^{\text {th }}, 2016\right)$.

4 The notion of "sweet colonization", which would have characterized the process of Portuguese maritime expansion, found in "salazarism" and in "lusotropicalism" their main ideological backings (Castelo, 1998). And no matter how much Vamireh Chacon $(2000,2002)$ hearkens to Gilberto Freyre's unawareness with regard to thinking, the hostility many researchers show lusotropicalism, the mere summoning thereof is anathema enough for many authors, wherein they denounce a condescending judgment concerning the historical violence that comprised colonialism (for instance: Alexandre, 1973; Bastide, 1972; Boxer, 1963).
} 
occurs between the people in that space, and also how interaction takes place among the citizens of the various Portuguese-speaking countries, because, in every case, we are dealing with territories marked by heterogeneity and the difference. However, when talking of the Portuguese-speaking space, we are talking about communities that officially express themselves in Portuguese, a language which, due to belonging to cultures, thinking and knowledge, also contributing toward building Portuguese-speaking communities, be they cultural, artistic or scientific.

Today, central in the academic community is the debate regarding scientific policies and on the means of counteracting the hegemonic model for making science, a model that does away with the difference, both by the usage language (English) and by the scientific paradigm called for (Anglo-Saxon) $)^{5}$. Undoubtedly, this concerns a strategic issue. A language that makes no effort to state the advances of its time, as well as its contradictions and anxieties, a language makes no effort to state the blockages and impasses of its time, i.e., a language with no thought, as it is a language that does not create knowledge. And, in not doing so, if it does not create knowledge, it is an archaic language, which stultifies and ends up dying 6 .

Performing this task, of making science in Portuguese, in every country speaking it, and also in its diasporas, means giving opportunities to knowledge, which is expressed in the diversity of cultures spoken in Portuguese, thereby contributing toward building a Portuguese-speaking, multi-centered and multifaceted scientific community, a community with human meaning, which is always a community with the sense of debate and cooperation, in respect for diversity and for the difference among cultures.

\section{THE NEW TECHNOLOGICAL CIRCUMNAVIGATION ${ }^{7}$}

The new technological circumnavigation, in Portuguese, comprises a cooperative, transnational and transcultural goal, an aim in scientific, pedagogical, cultural and artistic terms. Such a circumnavigation is expected to be able to develop literacies, promoting the culture of diversity and intercultural communication, in Portuguese-speaking countries and regions, as well as their diasporas. In fact, this was the meaning that was given, both to creating the Museu Virtual da Lusofonia [Lusophony Virtual Museum] ${ }^{8}$, at the University of Minho, in 2017, and to creating the Lusophone Journal of Cultural Studies $^{9}$, also at the University of Minho, in 2013.

\footnotetext{
${ }^{5}$ Regarding the generalization of English as the language of science and on the Anglo-Saxon paradigm for making science, I wrote the article, "A liberdade académica e os seus inimigos" [Academic freedom and its enemies] (Martins, 2015b).

${ }^{6}$ This viewpoint is articulated with the general goals of the work that I wrote regarding renewed research concerning culture, which opens today to cultural and scientific policies, and comprises ethnic, post-colonial, communication-related, anthropological ethnographic and feminist studies, signing a commitment with the current and the contemporary, which also means, with the present and the everyday (Martins, 2015d).

7 This section takes up a few paragraphs, rewriting them, from the study I conducted regarding communication of science, open access to knowledge and digital repositories (Martins, 2017).

${ }^{8}$ Available at http://www.museuvirtualdalusofonia.com/

${ }_{9}$ Available at http://www.rlec.pt/index.php/rlec
} 
In both cases, the idea is to constitute knowledge bases, that is, digital repositories and virtual museums, in Social and Human Sciences, at the Portuguese-speaking scale, that could represent, not just a major scientific assertion in Portuguese, but which also bring together a significant cultural and artistic corpus enabling us to understand the logic of interdependencies, from the standpoint of intercultural communication. That is, while deriving inspiration from Tzvetan Todorov (1982), the idea will be to use this scientific, cultural and artistic corpus to clarify our value judgments on the other, as well as the stereotypes with which we accommodate them. The idea will be to also clarify the concrete practices of assimilation, submission or indifference, relative to the other, as well as to counteract the "metaphysics of unity," which may be present in the notion of intercultural communication, if we happen to be unaware of the social processes of segregation, domination and seizing power (Martins, 2014).

Circumnavigation is a good metaphor for characterizing the current technological experience, given that this helps us think through the journey to be taken in that which is, after all, the contemporary experience par excellence ${ }^{10}$. The post-colonial circumstances are those of a world mobilized in its practices by all kinds of technologies, especially by mobile communication, information and leisure platforms (iPad, tablets, smartphones, etc.), by new forms of social interaction (social and technical networks) and by models arising from interaction (for example, apps and videogames).

In classical circumnavigation, there was the sextant, the astrolabe, the armillary sphere and the balestilha. However, in particular there were the stars, to guide us at night. In the meantime, we no longer looked at the stars and started looking at screens, as pointed out by Paul Virilio (2001, p. 135). That is, from the history of meaning in which the stars found themselves, the West paved the way to the screens, meaning, to "innovation, hybridity and interactivity" (Martins, 2011/12, p. 49).

The new media, or digital media, mean precisely that: communication mediated by computer, and, as a result, innovation, hybridity and interactivity. Innovation means practices calling for technological intervention. And because we are dealing with technological practices, we need to address, in digital media, first and foremost, programming and design (Foster, 2002).

In the meantime, concurrently with technological practices, we see the emergence of new communication practices calling for a change in the meaning of reading, as well as a change in the sense of glancing. Today, reading the newspaper, watching television or going to museum exhibits, are exercises in communication, all of which include practices of surfing the web, that is, communication practices, under specific conditions of time, space and interlocution: downloads, whether or not pirated, number of hits on Youtube, discussions on social media, expanding articles on blog posts, expanding images on YouTube videos.

\footnotetext{
10 The figure of circumnavigation, linked to the notion of technological journey, is originally developed in the Ph.D thesis of Stéphane Hugon, defended in 2007, at the Sorbonne, entitled, Circumnavigations, la construction sociale de l'identité en ligne. This thesis was published in 2010, while keeping the figure of circumnavigation in the title: Circumnavigations. L'imaginaire du voyage dans l'expérience internet. Aligning himself from the standpoint of "a sociology of electronic spaces", Hugon questions, among other aspects, "a culture of wandering," "a genealogy of drifting," "what it means to inhabit", "what a landscape is" and also "community dynamics".
} 
Digital media also mean hybridity, i.e., a synthesis made possible by the technical reality, making way for artificial beings, virtual worlds and simulating experiences. And, within this context, it's one thing, for instance, to engage in the reading process, characterized by Roman Jakobson, in Lingüística e Comunicação [Linguistics and Communication] (2003), which presumes an intersemiotic rendering, or of transmutation, in the process of interpreting verbal signs using non-verbal systems. Another thing altogether is the reading referred to in transmedia storytelling, or cross-media, which means expanding narrative, using various media (Sousa, 2018; Sousa, Martins \& Zagalo, 2016) "1.

Digital media also means interactivity, and not exactly interaction; that is, they mean social practices, which don't hearken merely to freedom and autonomy of social players; they also hearken to constraints of social action, which always occurs under specific conditions of time, space and interlocution.

And the current electronic programming and design devices, in a line of both continuity and split with the photo camera, are what generalize the image production process such as "drill and simulation" practices (Baudrillard, 1981), between recreational exchange and the daily sharing of digital images, in real and virtual environments of our cell phones and computers, identical to what happened, in the past, with postcards (Correia, 2013; and Martins \& Correia, 2014).

Thus, digital media mean new production practices of meaning, that is, new language and communication practices: on the one hand, multimodal or transmedia textualities ("hypertextualities"); and, on the other hand, forms of interactive digital communication. In the meantime, in this journey, we assign ourselves a "technological skin" (Kerckhove, 1997), a skin for affection, meaning, a skin for "being with others".

In the West, stars, in fact, have narrative virtualities: they have always guided us through journeys/voyages (seas, deserts and temptations); they had meaning, or rather, they inscribed us in a story of meaning, between a genesis and an apocalypse. And, upon inscribing us in this story of salvation, they always prevented us from capsizing. In Western culture, we even have a star par excellence: the one that, having risen in the East, has led the West for twenty centuries. Indeed, the star that guided the Three Wise Men led to the narrative of the Epiphany - the mystery of a God incarnate, who founded Western civilization in Christianity.

By taking up the imagination of the stars, the new circumnavigation, an electronic circumnavigation, brings about the new cybercultural paradigm, a journey to the New America of a new cultural archive, reactivating ancient forms in us, archaism, in short, mythology, while continually reconfiguring the community, through the longing to be with others ${ }^{12}$.

\footnotetext{
"Carlos Alberto Scolari (2011, p. 128) uses, as synonyms, the concepts of transmedia storytelling and cross-media, as he acknowledges that the latter is nonetheless more often used in professional circles than in academic ones. The term transmedia storytelling was coined by Henry Jenkins (2003). François Jost (2011, p. 95) prefers to speak of "intermedia struggle", instead of using the term convergence. Regarding transmedia storytelling, see also Christian Salmon (2007), who proposes a critical viewpoint on storytelling: "a story-making and spirit-formatting machine".

${ }^{12}$ I have developed the notion of cyberculture as technological circumnavigation, in other texts. In this regard, see: Maffesoli \& Martins, 2011, pp. 43-44; Martins, 2011a, pp. 18-19, 2011/2012, pp. 52-54, 2015a, pp. 37-43, 2017, pp. 21-26, 2015/2016, pp. 13-14.
} 


\section{THE JOURNEY OF TECHNOLOGICAL ATMOSPHERES AND LANDSCAPES}

The technological journey describes digital mutation, currently occurring in contemporary society and causes a convergence of information, media, art and culture technologies, while altering behaviors, attitudes and practices (Jenkins, 2008).

Therefore, since its purpose is to undertake the circumnavigation of a territory, made up of technological atmospheres and landscapes, in search of the new America of a new cultural archive, the technological journey, to be undertaken by Portuguese-speaking peoples, combines with the requirement calling for the use of three kinds of complementary literacies: a literacy of the media, which qualifies us for criticizing contents; an informative literacy, enabling an assessment of online documents and data; and also, a computational literacy, allowing us to surf and create online contents. The combination of these three kinds of media skills, in the technical age, is expected to boost civic participation and creative action, both online and offline.

Indeed, digital literacy needs to become central in the technological journey to be undertaken, so as to be creative in culture. Thus, the requisite of creativity in culture requires, of this technological journey, both cultural and artistic creation, under current technological conditions, and concern with citizenship and social inclusion (Kittler, 2011). This is why we cannot help but be confronted, as well, with the policies of full access to digital databases, virtual museums and repositories of open-access knowledge, which shape the practices of cultural agents today. In a nutshell, the technological journey to be undertaken by every Portuguese-speaking country cannot help but question these new contexts of meaning. This is not merely about questioning access to technologies and technological tools, but also about questioning access to civic participation and to cultural and artistic creation, in technological environments.

Without a doubt, today they comprise challenges to the technological journey, to new technological atmospheres, which put in place professionals' practices within the new digital context, particularly web designers, online curators, managers of virtual museums, web activists, and youtubers. Plus, they also constitute technological atmospheres that are challenging to the journey to be undertaken, the protection and safety of digital cultural contents, as well as communicating these contents.

Indeed, what concerns us in this new technological atmosphere is a culture in "status nascendi" (Maffesoli \& Martins, 2011, pp. 41-43), a culture that both comprises new tools, of artists and creators, and applies to archives, museums, video recordings and films. In short, this culture in "status nascendi" is a culture made up of technological landscapes.

Likewise, among other central issues of this cybercultural circumnavigation, we can highlight the formation of new audiences for cultures and the arts, as well as specific policies for digital repositories, always with a view to open access to knowledge.

What's more, within this context of technological circumnavigation, we mustn't forget material network environments, whose acquis are in flux. This means, for example, that plays, works and narratives, both cultural and artistic, can be transferred from one means of communication to another (transmedia remix) (Sousa, Zagalo \& Martins, 2012), and even converted, under license, into merchandise, or even giving rise to another product. 
Finally, we must not lose sight of the fact that digital culture needs to be underpinned in powerful physical territories and in heavy technological infrastructures. Because this is the only way we can create "cultural territories" serving sustained local development ${ }^{13}$.

\section{LUSOPHONY AS A FIGURE OF MODERNITY}

A notion of Lusophony, projecting the meaning of a community promise, must not remain unconnected to contemporary kinetics, which is a technological kinetics. Thus, we must be inscribed within the context of the debate on globalization, which is, as I pointed out earlier, a reality of an eminently economic and financial nature, controlled by information technologies. This notion of globalization gives us a defined identity, that is, definite, an identity of mobile, mobilizable, competitive and performing individuals in the global market (Martins, 2015b, pp. 9-10). Moreover, this expresses a cosmopolitan conception of culture, "a culture-world" (Martins, Cabecinhas \& Macedo, 2011), a "metaphysics of unity," served by a single language: English (Martins, 2014).

However, whereas it is true that the world has unified, via the expansion of financial and speculative capitalism, it has also diversified, through various resistances and adaptations (Sahlins, 1993, p. ix). As pointed out by Manuel Ivone Cunha, "global integration and local differentiation would be, to a certain extent, concurrent. Differentiation would develop in response to world integration" (Cunha, 2015, p. 277).

This is the context which, to me, can accommodate Lusophony, given that it is situated in what we could call "multiculturalist globalization", "Cosmopolitan globalization", founded in information technologies and in the economy, cannot be counteracted by lone and impotent individuals, or by Nation-states in crisis. This might be the case, however, for "multiculturalist globalization", bringing together peoples from extended geocultural areas, promoting and respecting the differences, while dignifying national languages. "Multiculturalist globalization" is the globalization of that which is diverse, of what is different, of that which is another. This occurs through the blending, the crossbreeding of ethnic groups, languages, memories and traditions (Martins, 2011b) ${ }^{14}$. And this is the purpose that we believe should serve Lusophony.

As for the figure of "portugality", the revenant that "vampirizes" the figure of Lusophony (Sousa, 2017), we need to align it alongside all other figures, ancient and modern, "vampirizing" it, be they luso-tropicalist or neocolonial figures, or figures of resentment - Portuguese, Brazilian, Mozambican or Angolan, or from other Portuguesespeaking countries ${ }^{15}$.

\footnotetext{
13 These were the principles that lent substance to the creation of the Museu Virtual da Lusofonia [Lusophony Virtual Museum], available at www.museuvirtualdalusofnia.com. Regarding the nature, goals and structure of the Lusophony Virtual Museum, see Martins, 2017, pp. 46-49.

${ }^{14}$ Regarding tension between cosmopolitan and multiculturalist globalization, see "Globalization and lusophone world. Implications for citizenship" (Martins, 2011b).

${ }^{15}$ Regarding the misconceptions interfering with the figure of Lusophony, see, for example, Martins, 2014, pp. 25-27.
} 
Indeed, this article essays on the possibilities of Lusophony, not like the imagination of a country, but as a linguistic and geocultural, transcultural and transnational space. We want to endow Lusophony with the meaning of an inextricably Portuguese, Brazilian, Angolan, Mozambican, Guinean, Cape Verdean, San Tomean, Timorese, Galician imagination, as well as all of these peoples' diasporas. As pointed out by José Luiz Fiorin (2006, p. 46),

there has to not be paternal authority from Lusitanian principles. (...) Lusophony shall not be the fatherland, as it will not be a space of power or authority. It shall be a motherland and a brotherland, as it should be the space of equals, of those with the same origin. Otherwise, it will not have any actual symbolic meaning, as it will be a space of empty discourse of a meaningless political jargon.

That is, the cultural space of Lusophony and the community and confraternity of common meaning and sharing can take place only on the assumption of plurality and difference and via in-depth knowledge of both sides.

To the question, "can subordinates speak?", back in the day asked by Gayatri Spivak (1988) against Western reason, we can, thus, reply with a notion of Lusophony, which is a struggle, not only through the assertion of plural difference, in which the Portuguesespeaking space is grounded, but also by the acknowledgment of diversity of peoples and cultures comprising them.

As we have sought to show, this understanding of Lusophony has nothing to do with "an empire nostalgia". It also has nothing to do with any historical justification of the colonial project which, in the past, mobilized European nations. The notion of Lusophony, thus, does not ignore logocentrism - a single discourse, which was also the unique meaning; ethnocentrism - a single narrative, between genesis and apocalypse, which contained the memory of a single and united people; imperialism, which served the reason of a single State; in short, colonialism, which fed slave traffic and imposed domination of southern peoples by northern ones.

\section{Communication Sciences and Portuguese-Speaking transcultural and TRANSNATIONAL SPACE}

It is the nature of Communication Sciences to deal with the processes of social meaning. Within this context, we have the study of narratives, which classically questioned their functions (Propp e Jakobson), their logic (Barthes, Greimas, Peirce), and the ways in which we derive sense from said logic (Bakhtin, Halliday, Metz, Baudrillard, Bourdieu). In the meantime, by dealing with digital media, Communication Sciences question technological visual narratives (Lev Manovich, Henry Jenkins, Kress, van Leeuwen, Jay Bolter, Richard Grusin, Steven Shaviro, Carlos Scolari).

And the technological visual narratives are what we are dealing with in this study. Because these are what constitute what is contemporary (Martins, 2007). By questioning 
our current experience, Communication Sciences allow us to see technological landscapes, expressing sensitive social atmospheres, and which hearken back to a time of complete mobilization to the market (Martins, 2010), and simultaneously hearken back to a troubled time, a time of continuous overheating. Thus, the technological visual narratives mobilize emotions and shape melancholy forms, resulting from the combination of techne and aesthesis, that is, between technique and emotion, and also, between techne e arche, meaning, between the new and the archaic (Martins, 2003, 2005, 2007, 2009; Martins, Oliveira \& Correia, 2011).

Now, with Portuguese-speaking countries summoned to undertake this technological journey, like someone opening "the last door into night" (Steiner, 1992, p. 6) ${ }^{16}$, due to the difficulty of the journey to be undertaken, I recall the Heidegger conference (1988, p. 38), pronounced in 1953, regarding "The question of technique" (Die Frage nach der Technik). Even though the German philosopher regards the technique as the danger, he argues with the verse by Hölderlin, but "There where the danger lies, so, too, does the one that saves grow".

This is the motto I use for the proposal I make for the Portuguese-speaking space. Technological circumnavigation, to which contemporaneity summons us, details the greatest event of the contemporary experience: the one merging techne and bios. Plus, we can view this experience as a condition for the possibility of a Portuguese-speaking circumnavigation, that is, as a condition for the possibility of a journey to be carried out by Portuguese-speaking peoples, in transcultural and transnational knowledge networks, which continually reconfigure the meaning of community, in short, the longing to be with others.

Translation: Traduções Técnicas do Minho, Lda.

\section{REFERENCES}

Alexandre, V. (1973). Le colonialisme portugais: réalité et mythe. In Suisse-Portugal, de l'Europe à l'Afrique (pp. 8-17). Genève.

Bastide, R. (1972). Lusotropicology, race, nationalism, class protest and development in Brazil and portuguese Africa. In R. H. Chilcote (Ed.), Protest and resistance in Angola and Brazil (pp. 225-240). Berkeley: University of California Press.

Baudrillard, J. (1981). Simulacres et simulation. Paris: Galilée.

Bourdieu, P. (1977). Sur le pouvoir symbolique. Annales, 32(3), 405-411.

Bourdieu, P. (1979). La distinction. Critique sociale du jugement. Paris: Éditions de Minuit.

\footnotetext{
${ }^{16}$ Wanting to specify the meaning of the journey he wants to undertake with us, in the essay "for a redefinition of culture," Steiner writes on the frontispiece: "it would be said that we are, with regard to a theory of culture, at the same point where Bartok's Judith, when she asks to open the last door to the night" (Steiner, 1992, p. 6). Steiner summons the character Judith, from the libretto from one of the operas by Bartok, who used the traditional tale as a model, No Castelo do Barba Azul [In the Castle of Bluebeard]. And his essay on contemporary culture, a culture of a technological nature, is an open door on "The great tedium" (title of the first chapter); on "A season in Hell" (title of the second chapter), on "Post-culture" (title of the third chapter).
} 
Bourdieu, P. (1982). Ce que parler veut dire. Paris: Fayard.

Boxer, C. (1963). Race relations in the portuguese colonial empire, 1415-1825. London: Oxford University Press.

Brito, R. \& Martins, M. L. (2004). Moçambique e Timor-Leste: onde também se fala o português. In Livro de Atas do III Congresso da Sopcom. Covilhã: Universidade da Beira Interior. Retrieved from http://hdl. handle.net/1822/1005

Castelo, C. (1998). "O modo português de estar no mundo". O luso-tropicalismo e a ideologia colonial portuguesa (1933-1961). Porto: Afrontamento.

Chacon, V. (2000). Gilberto Freyre, a globalização e o luso-tropicalismo. In A. Moreira \& J. C. Venâncio (Eds.), O luso-tropicalismo. Uma teoria social em questão (pp. 33-41). Lisboa: Veja.

Chacon, V. (2002). O futuro da lusofonia. Lisboa: Verbo.

Correia, M. L. (2013). Intermitências na cultura visual contemporânea: o postal ilustrado e a imagem recreativa. Doctoral thesis in Communication Sciences, University of Minho, Braga, Portugal. Retrieved from http://hdl.handle.net/1822/29216

Cunha, M. I. (2015). As duas faces da cultura: usos e sentidos de uma noção. J. In Y. Durand \& H. Martins, Olhares e oficios de antropólogos em Espanha e Portugal (pp. 269-291). Braga: CRIA-UMinho. Retrieved from http://hdl.handle.net/1822/40115

Faraco, C. A. (2016). História sociopolítica da língua portuguesa. São Paulo: Parábola.

Faraco, C. A. (2012). Lusofonia: utopia ou quimera? Língua, história e política. In L. Tânia, Z. Carneiro, J. Soledade, A. Almeida \& S. Ribeiro (Eds.), ROSAE. Linguística, História, história das línguas e outras histórias (pp. 31-50). Salvador: EDUFBA.

Fiorin, J. L. (2006). A lusofonia como espaço linguístico. In N. Bastos (Ed.), Língua portuguesa: reflexões lusófonas (pp. 25-48). São Paulo: EDUC.

Foster, H. (2002). Design and crime (and other diatribes). Nova lorque: Verso.

Heidegger, M. (1954/1988). La question de la technique. In Essais et conférences (pp. 9-48). Paris: Gallimard.

Hugon, St. (2010). Circumnavigations. L'imaginaire du vopage dans l'expérience Internet. Paris: CNRS Éditions.

Jakobson, R. (1970). Lingüística e Comunicação. São Paulo: Cultrix.

Jenkins, H. (2008). Convergence culture - where old and new media collide? New York: New York University Press.

Jenkins, H. (2003). Transmedia storytelling. MIT Technology Review. Retrieved from https://www. technologyreview.com/s/401760/transmedia-storytelling/

Jost, F. (2011). Novos comportamentos para antigas mídias ou antigos comportamentos para novas mídias? Matrizes, 4(2), 93-109. Retrieved from https://www.revistas.usp.br/matrizes/article/ download/38294/41119

Jünger, E. (1930/1990). La mobilisation totale. Paris: Gallimard.

Kerckhove, D. de (1997). A pele da cultura - uma investigação sobre a nova realidade electrónica. Lisboa: Relógio D’Água.

Kittler, Fr. (2011). Técnicas artísticas. In M. T Cruz (Ed.), Novos média. Novas práticas (pp. 10-19). Lisboa: Vega. 
Lopes, A. J. (2004). A batalha das línguas. Perspectivas sobre Linguística Aplicada em Moçambique. Maputo: IUEM/Fundação Universitária, UEM.

Maffesoli, M. \& Martins, M. L. (2012). Ciberculturas. Revista de Comunicação e Linguagens, 42, 41-52. Retrieved from http://hdl.handle.net/1822/23794

Martins, M. L. (1998). A biblioteca de Babel e a árvore do conhecimento. O Escritor, 11/12, 235-240. Retrieved from http://hdl.handle.net/1822/30068

Martins, M. L. (2003). O quotidiano e os média. Todas as Letras, 5, 97-105. Retrieved from http://hdl.handle. net/1822/1064

Martins, M. L. (2005). Espaço público e vida privada. Revista Filosófica de Coimbra, 27, 157-172. Retrieved from http://hdl.handle.net/1822/23799

Martins, M. L. (2007). Nota introdutória. A época e as suas ideias. Comunicação e Sociedade,12, 5-7. DOI: $10.17231 /$ comsoc.12(2007).1092

Martins, M. L. (2009). Ce que peuvent les images. Trajet de l'un au multiple. Les Cahiers Européens de l'Imaginaire, 1, 158-162. Retrieved from http://hdl.handle.net/1822/24132

Martins, M. L. (2010). A mobilização infinita numa sociedade de meios sem fins. In C. Álvares \& M. Damásio (Eds.), Teorias e práticas dos media. Situando o local no global (pp. 267-278). Lisboa: Edições Lusófonas. Retrieved from http://hdl.handle.net/1822/24250

Martins, M. L. (2011a). Crise no castelo da cultura. Das estrelas para os ecrãs. Coimbra: Grácio Editor. Retrieved from http://hdl.handle.net/1822/29167

Martins, M. L. (2011b). Globalization and lusophone world. Implications for citizenship. In M. Pinto \& H. Sousa (Ed.), Communication and citizenship: rethinking crisis and change (pp. 75-84). Coimbra: Grácio Editor. Retrieved from http://hdl.handle.net/1822/25344

Martins, M. L. (2011/12). Média digitais - hibridez, interatividade, multimodalidade. Revista de Comunicação e Linguagens, 43-44, 49-6o. Retrieved from http://hdl.handle.net/1822/25606

Martins, M. L. (2014). Língua Portuguesa, globalização e lusofonia. In N. M. Bastos (Ed.), Língua portuguesa e lusofonia (pp. 15-33). São Paulo: EDUC - IP-PUC. Retrieved from http://hdl.handle.net/1822/29178

Martins, M. L. (2015/2016). Ciências da Comunicação e mundo Lusófono. Anuário Internacional de Comunicação Lusófona, XIII, 11-18. Retrieved from http://hdl.handle.net/1822/45164

Martins, M. L. (2015a). Média digitais e lusofonia. In M. L. Martins (Ed.), Lusofonia e interculturalidade promessa e travessia (pp. 27-56). Famalicão: Húmus. Retrieved from http://hdl.handle.net/1822/39698

Martins, M. L. (2015b). Lusofonias - reinvenção de comunidades e combate linguístico-cultural. In M. L. Martins (Ed.), Lusofonia e interculturalidade - promessa e travessia (pp. 7-23). Vila Nova de Famalicão: Húmus. Retrieved from http://hdl.handle.net/1822/39703

Martins, M. L. (2015 c). A liberdade académica e os seus inimigos. Comunicação e Sociedade, 27, 405-420. DOI: $10.17231 /$ comsoc.27(2015).2109

Martins, M. L. (2015 d). Os Estudos Culturais como novas Humanidades. Revista Lusófona de Estudos Culturais / Lusophone Journal of Cultural Studies, 3(1), 341-361. Retrieved from http://hdl.handle. net/1822/40655 
Martins, M. L. (2017). Comunicação da ciência, acesso aberto do conhecimento e repositórios digitais o futuro das comunidades lusófonas e ibero-americanas de Ciências Sociais e Humanas. In M. L. Martins (Ed.), A internacionalização das comunidades lusófonas e ibero-americanas de Ciências Sociais e Humanas o caso das Ciências da Comunicação (pp. 19-58). Vila Nova de Famalicão: Húmus. Retrieved from http:// hdl.handle.net/1822/51039

Martins, M. L. (2018a). A lusofonia no contexto das identidades transnacionais e transcontinentais. Letrônica - Revista do Programa de Pós-graduação em Letras da PUCRS, 11(1), 3-11. DOI: $10.15448 / 1984-4301.2018 .1 .30438$

Martins, M. L. (2018b). Communication studies cartography in the lusophone world. Media, Culture a Society, 4O(3), 458-463. DOI: 10.1177/0163443717752812

Martins, M. L., Cabecinhas, R. \& Macedo, L. (Eds.), (2011). Anuário Internacional de Comunicação Lusófona, Lusofonia e Cultura-Mundo, IX. Braga: Universidade do Minho/Grácio Editor. Retrieved from http://hdl. handle.net/1822/36686

Martins, M. L. \& Correia, M. L. (Eds.) (2014). Do post ao postal. Famalicão: Húmus. Retrieved from http://hdl. handle.net/1822/35295

Martins, M. L., Oliveira, M. \& Correia, M. L. (2011). Les images numériques s'imaginent l'archaïque: mettre en perspective les cartes postales. Sociétés, 111, 163-177. DOI: 10.3917/soc.111.0163

Morin, E. (1962). L'esprit du temps. Paris: Grasset.

Mungioli, M. C. (2011). A construção de mundos possíveis se tornou um processo coletivo. Interview with Carlos Alberto Scolari. Matrizes, 4(2), 127-136. Retrieved from www.revistas.usp.br/matrizes/article/ download/38296/41123/

Sahlins, M. (1993). Goodbye to "Tristes Tropiques": ethnography in the context of Modern History. Journal of Modern History, 65, 1-25.

Salmon, Ch. (2007). Storytelling. La Machine à fabriquer des histories et à formater les esprits. Paris: La Découverte.

Sloterdijk, P. (2000). La mobilisation infinie. Paris: Christian Bourgois.

Sousa, M. N. (2018). A propagação de histórias através de múltiplos média. Por um modelo conceptual de transmediações, adaptações e outros exercícios derivativos. Doctoral thesis in Communication Sciences, University of Minho, Braga, Portugal. Retrieved from https://repositorium.sdum.uminho.pt/ handle/1822/56395

Sousa, M. N., Zagalo, N. \& Martins, M. L. (2012). Eu também posso propagar histórias. A adaptação e as narrativas transmediáticas na era da participação". Comunicação e Sociedade, 22, 167-183. DOI: 10.17231/ comsoc.22(2012).1280

Sousa, M. N., Martins, M. L. \& Zagalo, N. (2016). Transmedia storytelling: the roles and stakes of the different participants in the process of a convergent story, in divergent media and artefacts. In A. Lugmayr \& C. Dal Zotto (Eds.), Media convergence handbook (Vol.2, pp. 117-135). Berlin/Heidelberg: Springer-Verlag.

Sousa, V. (2017). Da 'portugalidade' à lusofonia. Famalicão: Húmus.

Spivak, G. (1988/1994). Can the subaltern speak? In P. Williams \& L. Chrisman, Colonial and Post-colonial theory. A reader (pp. 66-111). New York: Columbia University Press.

Steiner, G. (1971/1992). No Castelo do Barba Azul. Notas para a redefinição da cultura. Lisboa: Relógio d'Água. 
Todorov, T. (1982). La Conquête de l'Amérique. La question de l'autre. Paris: Éditions du Seuil.

Tamen, M. (2018, junho). Ler (entrevista), 149, 20-33.

Tamen, M. (2016, 8 de janeiro). Língua portuguesa. A política da língua. Observador. Retrieved from https:// observador.pt/opiniao/politica-da-lingua/

Tamen, M. (2012, 24 de abril). Miguel Tamen. A lusofonia é uma espécie de colonialismo de esquerda. $i$. Retrieved from https://ionline.sapo.pt/467762

Virilio, P. (2001). Entretien avec Paul Virilio. Le Monde de l'Éducation, 294, 135-138.

\section{BIOGRAPHICAL NOTE}

Moisés de Lemos Martins is Professor of Sociology of Culture and Communication at the University of Minho (Braga, Portugal). Director of the Communication and Society Research Centre (CECS), which he founded in 2001. He is the author of a vast body of academic work in the field of the epistemology and sociology of communication.

ORCID: https://orcid.org/oooo-0003-3072-2904

Email: moisesm@ics.uminho.pt; moiseslmartins@gmail.com

Address: Communication and Society Research Centre (CECS), Campus de Gualtar, University of Minho, Braga 4710-057, Portugal

\section{* Submitted: 04.05.2018}

*Accepted: 03.07.2018 